\title{
Henry Corbin's Oriental Philosophy and Iranian Nativist Ideologies
}

\begin{abstract}
Ahmad Bostani
Department of Political Science, Faculty of Law and Political Science, Kharazmi University, Tehran 1571914911, Iran; abostani@khu.ac.ir

Abstract: This paper aims to explore the roots of the nativist discourse among Iranian intellectuals in the 20th century prior to the Islamic Revolution, a discourse based on Eastern authenticity and the felt need for a return to Islamic, Persian, or Asian traditions. This general tendency took various forms among anti- and even pro-regime intellectuals, including severe anti-modernist evaluations of Al-e-Ahmad, Hossein Nasr, Ahmad Fardid, and Ehsan Naraqi. This nativist movement, as some scholars have shown, played a significant role in the victory of the Islamic Revolution in 1979. This paper aims to discuss some philosophical origins of these East-based and anti-West ideologies in the specific interpretation of Henry Corbin of the East/West spiritual split. This paper demonstrates that these ideas, to a considerable extent, stemmed from Corbin's "Eastern scheme," based on the authenticity of spiritual illumination. This paper explores how this Oriental philosophy, rooted in ancient Persia and medieval Iranian wisdom, has been used for political purposes through the ideologization of tradition in contemporary Iran. Therefore, it discusses Corbin's theological scheme's political and social ramifications to demonstrate the traces of his scheme in the works of a few nativist intellectuals in an ideologized form.
\end{abstract}

Citation: Bostani, Ahmad. 2021 Henry Corbin's Oriental Philosophy and Iranian Nativist Ideologies. Religions 12: 997. https://doi.org/ $10.3390 /$ rel12110997

Academic Editors: Kristin Joachimsen and Marianne Hafnor Bøe

Received: 10 August 2021

Accepted: 11 November 2021

Published: 14 November 2021

Publisher's Note: MDPI stays neutral with regard to jurisdictional claims in published maps and institutional affiliations.

Copyright: (C) 2021 by the author. Licensee MDPI, Basel, Switzerland. This article is an open access article distributed under the terms and conditions of the Creative Commons Attribution (CC BY) license (https:// creativecommons.org/licenses/by/ $4.0 /)$.
Keywords: nativism; authenticity; Oriental philosophy; Persian identity; Henry Corbin

\section{Introduction}

Henry Corbin (1903-1978) was an influential scholar of Islamic philosophy and Shiite theology who edited, translated, and introduced several important works of crucial Muslim thinkers and mystics. However, his significance to Iranian intellectual history was not confined to his "scholarly" activities as a specialist of Islamic philosophy, Shiism, and Iranian esotericism (Nasr 1977, p. 25). Rather, his influence on contemporary Iranian intellectual history has gone beyond that and consists of a broader social-intellectual impact, with some political and ideological ramifications.

A few scholars have addressed the connection between Corbin's scheme and politics. Some of Corbin's European disciples have attempted to provide political or social theories based on his conception of esotericism, imagination, and metahistory (e.g., Durand 1977; Jambet 1983). According to some of them, Corbin's philosophy has a large capacity for providing political concepts such as freedom and individualism (Cheetham 2003, p. 108; Hillman 2006, p. 142). They also emphasize Corbin's “anti-totalitarian" motivations based on his conception of modern ideologies as secularized versions of ancient theological deviations. In some of his works, Corbin briefly offered a theological genealogy of contemporary Marxism and totalitarianism based on their theological roots (Corbin 1985).

Corbin's philosophical and theological ideas, including his "Oriental" scheme, had significant political implications. Some scholars, such as Wasserstrom, John Walbridge, and Ali Mirsepassi, have demonstrated the deficiencies and detrimental political and social aspects and results of his supposedly anti-political ideas (Wasserstrom 1999; Mirsepassi 2017, pp. 111-43; Walbridge 2001). However, the discussion in this paper concerning the political ramifications of Corbin's scheme is from a political-theological framework, and I want to emphasize 
the potential of Oriental philosophy to become ideologized. On the other hand, what is at stake here is not the political aspects of Corbin's project, as Wasserstrom and Mirsepassi claimed. They emphasize the connection between Corbin's theological schemes on the one hand, and the sociopolitical ambitions of the Shah's regime or Paul Mellon's Bollingen foundation on the other hand. ${ }^{1}$

This paper aims to show that Corbin's scheme was prone to ideologization, regardless of its own political aspects. According to Corbin's theology, the material world has no originality, and the collective or individual consciousness must be considered and understood in connection to the spiritual or imaginal world. Thus, although Corbin's disciples in Iran negate the political in the ordinary sense of the term, they would embrace a political ideology within Corbin's Oriental scheme. According to this view, an ideal community should be based on the imaginal connection, which is vertical, hierarchical, and transcendental. This paper aims to show that this theological worldview is highly prone to be ideologized. Therefore, the first section will discuss the theoretical framework of the research, namely the process of the ideologization of tradition in Iran. The second section will introduce the Oriental scheme in Iranian philosophy according to Henry Corbin's account. The third section gives an overview of the status of political and historical dimensions in Corbin's scheme, arguing that his conception of Iranian tradition was de-politicized since he attempted to provide a non-historical account of this tradition. The last section concludes on the ideologization of the Oriental philosophy and demonstrates the traces of Corbin's scheme in the works of a few nativist intellectuals in an ideologized form.

\section{Ideologization of Tradition in Contemporary Iran}

In this paper, I will use the concept of the ideologization of tradition as the theoretical framework to discuss the relationship between Corbin's Oriental philosophy inspired by medieval Iranian philosophers and contemporary nativist and Anti-Western ideologies. In order to show this transformation from the spiritual and theological realm into the political and ideological domain, some scholars discussed the process of the ideologization of tradition, religion, and spirituality (Shayegan 1991). According to Shayegan, for instance, the process of ideologization could transform any spiritual content to closed ideological systems through which tradition acquires the shape of modern ideologies although it continues to claim authenticity. The main features of such ideologies are the "dangerous excess of dogmatization" (Shayegan 1992, p. 141), the friend/foe distinction, and the need for purgation based on spiritual and religious beliefs (Hansen 2009, p. 1029).

As some scholars argue, in the 20th century, the phenomenon of the ideologization of Islamic tradition appeared as a reaction to the process of Western secularization, both globally and nationally. Hence, this process should be viewed in the broader framework of the relationship between Muslim countries and the West, especially as the response to the political suppression made by secular governments. As Waardenburg explains,

"These ideologies are to be read as protests against Western dominance and a self-defense against Western encroachments on Islamic identity. The movements of political independence were only one attempt to restore a balance and develop more equal relationships between the Muslims and the rest of the world, including the West .... .. The encounter with the West, read at first as an encounter with Christianity, quickly turned out to be an encounter with a Western form of secularity and its ideological expression as "secularism". Whereas at the beginning the ideologization of Islam may have been largely a response to Christianity, in the second half of the twentieth century it rather became a response to secularism as found in and ascribed to the West. The confrontation with secularism forced Muslims to formulate anew what is essential in Islam as a religion and to present this in a concentrated form to the Muslim community-and to Westerners, if needed". (Waardenburg 2002, p. 324)

Waardenburg distinguishes two types of ideologization based on "essentialization" and "adaptation", respectively. Through the adaptation process, an ideological and utopian 
version of spirituality is formulated to offer a solution to perceived political or social problems (ibid, pp. 319-20). The ideological adaptation of tradition that aims to serve a practical purpose is more relevant to our study of the ideologization of Oriental spirituality in mid-20th century Iran.

An allusion to the socio-political context of this ideological adaptation in contemporary Iran is necessary. Corbin's presence in Iran falls in the sensitive period between two major political events: the coup of 1953 and the Revolution of 1979. In this 26-year period, which coincided with increasing oil revenue, the Shah undertook major economic and cultural development programs with the help of some Western-educated individuals who were appointed to ministerial and administrative posts. The White Revolution in 1963, for instance, was a top-down modernization program, which altered rural economies and led to rapid urbanization and Westernization. As a result, the royal regime faced criticism from religious and intellectual movements that regarded these modernist cultural and rural changes as antithetical to Islamic, Iranian, Eastern and generally traditional values. Most significantly, the religious clerics and their supporters and the left-wing guerrilla groups who attempted to overthrow the pro-Western regime are worth mentioning. Moreover, an intellectual tendency, mainly among some philosophers and sociologists, started to exert influence on intellectual and artistic movements of this period, especially over the last two decades of the royal regime. This tendency, called "nativism" by some scholars (Boroujerdi 1996), was a discourse based on Eastern 'authenticity' and the felt need for a return to Islamic, Persian, or Asian traditions. This general tendency took various forms among antiand even pro-regime intellectuals, including severe anti-modern evaluations of, among others, Al-e-Ahmad, in his well-known Westoxication, Dariush Shayegan in Asia confronting the West, and Ehsan Naraqi in The Alienation of the West. According to some scholars, this nativist movement played a significant role in the victory of the Islamic Revolution in 1979 (see: Mirsepassi 2017, 2019), even though some of the nativist thinkers, such as Naraqi, Shayegan, and S.H. Nasr, were close to the court or at least not regarded as the opposition.

This research does not aim to discuss, evaluate, or criticize the nativist movement. Instead, it aims to explore some of the philosophical and metaphysical roots of these Eastbased and anti-West ideologies in the specific interpretation of Henry Corbin's East/West split. We will demonstrate that these ideas are largely rooted in Corbin's Eastern scheme, which took an ideologized form.

\section{Henry Corbin and the Oriental Philosophy}

Corbin's academic career in Iran, from 1946 to 1978, was a period in world history immediately preceded by multiple upheavals of emigration, defeat, genocide, war, and revolution. As a scholar observed, it is not surprising that the theme of renovatio preoccupied him, like many other thinkers of the period. According to Corbin, "a 'tradition' is transmitted in a living state only through a continual rebirth." (Corbin 2001, p. 255). Corbin's scheme was an indirect response to the crises he lived (Wasserstrom 1999, p. 127). In 1946, after editing and publishing some of Suhrawardi's works, he was appointed as the director of the Department of Iranology at the French-Iranian Institute in Tehran and remained at that position until 1975. During this long period, he divided his time between Paris and Tehran. With the collaboration of several Iranian scholars, he embarked upon the editing and publication of many classical texts and treatises which mostly belonged, according to Corbin's interpretation as developed fully in his En Islam iranien, to a distinctly Iranian trend in theosophy with a long and evolving tradition of its own (Boucharlat 2012, p. 176). For Corbin, the study of Iranian intellectual history was not confined to scholarly concerns but was a philosophical and ontological preoccupation: based on notions of tradition, authenticity, and spirituality, Iran was for him an eternal realm that could provide an alternative to Western intellectual and social systems whose failure turned out to be apparent at that time (Corbin 1985, p. 47).

Corbin had a trans-historical conception of Iranian tradition, arguing that the scholar of religion must not reduce spiritual phenomena to history, sociology, and psychology. Rather, 
these phenomena should be understood as they originally are uncovered to traditional practitioners and believers, i.e., great sages and Sufis (Hughes 2003, p. 32). This process of uncovering and unveiling, which is rooted in Martin Heidegger's inspiration, represents the concept of "authenticity" in his metaphysical scheme. According to his phenomenological approach, a living tradition requires "sympathy carried to the point of identification" (Adams 1985, p. 142). Thus, the encounter with tradition is not an objective enterprise, but the interpreter must participate in a trans-historical cosmic process. Iranian identity and continuity must be understood within this cosmic worldview. Corbin was convinced that an Iranian Weltanschauung persisted throughout Iranian intellectual history and beyond the material and historical course of events. This worldview existed before and after the reign of Islam in Iran. Corbin, in his various books and articles, discussed this continuity of Iranian identity. The cosmic scheme of Corbin, based on which he interpreted Iranian identity, includes features such as cosmic verticality, cyclic temporality, metahistory, and the duality of East/West. However, according to him, the key to entering the Iranian spiritual world was the imaginal world within which the above features could be understood epistemologically and ontologically (Corbin 1971, pp. 60-61; Corbin 1991, pp. $61,169,183)$.

The term 'imaginal world', a Corbinian neologism, denotes a world between the intelligible realm and the sensible world, in which all spiritual phenomena like revelation, intuition, and miracles find a satisfactory explanation. This is, as Corbin writes, "the world in which real spiritual events "take place," real, however, not in the sense that the physical world is real, or yet in the sense that events chronologically recorded to "make history" are real, because here the event transcends every historical materialization. It is an "external world," and yet it is not the physical world. It is a world that teaches us that it is possible to emerge from measurable space without emerging from extent, and that we must abandon homogeneous chronological time in order to enter that qualitative time which is the history of the soul" (Corbin 1989, p. XXVI). Corbin, in his various books, attempted to demonstrate the continuity of this world as a supportive idea for spiritual experiences from ancient Iran to the Islamic period (Corbin 1946). Hence, the Iranian world and its persistence over its long history is connected to this "earth of visions."

Corbin's conception of the Iranian worldview faces several serious problems. First, it empties Islamic philosophy of its rational and epistemological dimensions by emphasizing a non-rationalist interpretation of philosophy among Iranian sages. That is why, as some scholars have demonstrated, he overlooked the rational, logical, and physical parts of Islamic philosophers such as Alfarabi, Avicenna, and Suhrawardi, regarding them as spiritual sages and esoteric mystics, rather than philosophers stricto sensu (Ziai 2013; Rahman 1975, p. VII). Preferring the term "theosophy" to philosophy for describing their intellectual enterprise, Corbin undermined the philosophical value of their investigation and reduced them into spiritual and mystic insights. On the other hand, he also overlooked the social, civilizational, and historical dimensions of the doctrines of Islamic and Iranian theologians and philosophers (See: Walbridge 2001, pp. 107-10; Green 2005, p. 224). As Hamid Algar observed, Corbin's scheme was against not only historicism, but also it disdained history itself (Algar 1980, p. 90). This disdain of rational and historical aspects led Corbin to a specific interpretation of Iranian spiritual tradition, which was not only selective but divorced this tradition from its underlying context. That is why Corbin overemphasized the esoteric and Oriental aspects of Iranian tradition, particularly in his study of the philosophical and spiritual legacy, and looked at it through a specific lens (Rousse-Lacordaire 2006, p. 272).

The most crucial aspect of Corbin's scheme, which is highly relevant to our study of Iranian ideologies, is called "Oriental" or "Eastern" Philosophy. Oriental philosophy is the "lost continent" he discovered in the Iranian world and the hallmark of his own philosophical and theological system. Corbin's interpretation of philosophy in Iran is based on this crucial concept. According to him, despite Avicenna being known as a Peripatetic philosopher, his personal undertaking was to culminate an 'Oriental philosophy' 
(Corbin 2001, p. 169). Instead of analyzing Avicenna's encyclopedic works such as Shifa', Corbin emphasized some peripheral treatises whose significance was overlooked by previous scholars of Islamic philosophy (Nasr 1978, 186 sq.). For instance, he devoted a whole book to the meticulous study of Avicenna's symbolic recitals, namely Hayy ibn Yaqzan, Salaman and Absal, and the Recital of the Bird (Corbin 1960). He criticized scholars such as A. Badawi, who maintain that in Avicenna's terminology, the Orientals are "the Peripatetic of Bagdad, contemporaries of Avicenna", as opposed to "the Greek commentators on Aristotle (Alexander of Aphrodisias, Themistius, and John Philopon) as representatives of the 'Occidental' doctrine." (Corbin 1960, p. 272). He argues against the scholars who interpret the Avicennian oriental/occidental split in the geographical sense of the term, ${ }^{2}$ insisting that Avicenna's recitals should be understood as symbolic works narrating the events that occurred in the imaginal world, celestial earth, or the "eighth climate." As S.H. Nasr observed,

"Often they (European scholars) have overlooked the wisdom of the Arabic language itself in which "light," or "illumination, "possesses the same root as "East" or "Oriental," conforming to the obvious solar symbolism. In fact, this double meaning of the root (shrq) itself plays a major role in the whole plan of the visionary narratives where the East is identified with the realm of the spiritual and intelligible essences, or the realm of light, and the West with the material and corporeal world, or the realm of darkness". (Nasr 1978, p. 186)

Corbin's topography is based on spiritual and esoteric symbolism, drawing a clear-cut distinction between symbol and allegory (Corbin 1972b, pp. 86-87). According to him, symbolism reveals something that cannot be expressed otherwise. It is the only possible expression of the thing symbolized. On the other hand, Allegory is the artificial figuration of generalities or abstractions that can perfectly be expressed and known in other ways. ${ }^{3}$ Corbin believes that higher truths are ineffable and that only symbols can approach them. The symbol is like silence: it says, and it does not say, but eventually, it cannot be deciphered once and for all (Corbin 1972b, p. 72). In Corbin's hermeneutics, symbols are irrefutable: "one can understand them, one can refuse them, but they are not such that one can refute them" (Corbin 1981, p. 28). In such a configuration, critical thinking will be impossible since the structure of the text, as a network of symbols, exists in a way that exceeds any evaluation. ${ }^{4}$

Corbin argues that Islamic philosophy in Iran, unlike the Western part of the Islamic world, has followed an Oriental pattern of wisdom, which attempted to overcome the Peripatetic and rationalist trends and provide a spiritual and cosmic philosophy based on ancient Eastern and especially Persian traditions. Hence, Alafarabi, Avicenna, Suhrawardi, and Mulla Sadra, among many others, must be understood within this Oriental scheme. Suhrawardi believed that Avicenna failed to provide an Oriental philosophy since he had no access to the Oriental principle (asl al-mashriqi), which had been present at the time of the Ancient Persian sages (Sohrevardi 2001a, p. 195). Based on this statement, Corbin argues that Avicenna's Oriental philosophy reached its peak in Surawardi's Philosophy of Illumination.

Among his recitals, one got more attention due to its symbolic title: Ghesseh-ye Ghorbat$e$ Gharbi (the Recital of Occidental Exile), which could be construed as the continuation to Avicenna's Oriental scheme. According to Corbin,

"The idea of the Orient as it is expressed in Avicenna's recital of Hayy ibn Yaqzan is the same as al-Suhrawardi. He is so well aware of this that when, following Avicenna's example, he writes symbolic recitals of spiritual initiation, he praises Avicenna's recital, but only in order to emphasize the fact that his own 'Recital of the Occidental Exile' begins at the point where Avicenna's ends, as if he is making a gesture of supreme significance. What left him dissatisfied with Avicenna's symbolic recital corresponds to what left him dissatisfied with the fragments of his teaching. Avicenna had, to be sure, formulated the project of an 'Oriental 
philosophy', but the project was bound to fail, for a decisive reason. Consequently it is to the study of his own book that the 'Shaykh al-Ishraq' invites anyone who wishes to be initiated into 'Oriental wisdom". (Corbin 2001, pp. 206-7)

Occidental exile, for Suhrawardi, symbolizes the ontological situation of the human soul as "prisoner in the land of the Occident" and eager to be saved "from the prison of nature and the impediment of matter." (Sohrevardi 2001b, p. 296). The Suhrawardian synthesis of Platonic philosophy and Persian wisdom consists of, according to Corbin, a crucial moment of the Oriental tradition. Suhrawardi's opposition between Orient and Occident, which is expressed within his philosophy of illumination based on light and darkness, is the hallmark of his Oriental scheme and a key to understanding his theoretical and narrative treatises (Corbin in Sohrevardi 2001a, p. XLIV). This hierarchy of Orient and light, which stands in sharp opposition to the darkness of the Occident, shapes the overall topography of Corbin's thought and work. His entire intellectual program seeks illumination and spiritual enrichment, which includes "an insightful understanding of the movement of the mind and spirit idealized as the pilgrimage of the soul to the source of light, to the Orient, where certainty and vision go together" (Elmarsafy 2021, p. 61).

\section{Oriental Esotericism and the Political}

Corbin's esoteric thought and his approach toward traditional doctrines have some features rooted in his metaphysical Weltanschauung, which may be called "cosmic," and in his metaphysics of imagination or the imaginal. As Antoine Faivre explains about Corbin's idea of the imaginal world, a cosmic view can be defined as a knowledge of connections uniting the individual to higher entities, to cosmic forces, and living Nature (Faivre 1994, p. 21). Here I will try to analyze Corbin's esotericism based on its potential political ramifications.

Corbin's cosmic Weltanschauung regards human beings according to their relation to the cosmic order. This connection is both epistemologically and ontologically meaningful. Knowledge, thinking, and consciousness are the results of connecting to this cosmic order. This cosmic worldview has some essential features: the duality of East/West, monism, holism, cyclic temporality, hierarchical order, esotericism, and the opposition between the esoteric and exoteric. Therefore, he was attracted by Islamic $t a^{\prime} w i l$, which goes from the exoteric or apparent aspect (zahir) into the esoteric meaning (batin), to unveil the hidden truth. It is to restore to one's origin and the place where one comes home; consequently, it is to return to the true and original meaning (Corbin 1960, p. 29). Corbin's conception of ta'wil is based upon a cosmological system, which comprehends the unity of the universe in terms of two arcs of descent and ascent (Corbin 1972a, p. 15). According to this hermeneutical strategy, rooted in neo-Platonic doctrines, a living tradition includes unfolding the universe. Hence, authenticity requires the relationship of the individual soul to this process.

Corbin dismisses the political and even social aspects of Iranian tradition. This dismissal is present everywhere in his writings, even in his historiography of Islamic and Iranian philosophy. For instance, he analyzes Alfarabi, the most important political philosopher of Islamic civilization, as if he was just a metaphysician. According to Corbin, a political interpretation of classical philosophers would amount to a modern misunderstanding of their doctrines and requires reducing the esoteric doctrines to exoteric teachings (Corbin 1996, p. 5). In his esoteric conception, focusing on the political and worldly aspects of ancient doctrines would be withdrawing them from their presuppositions and perspectives to impose modern assumptions (Landolt 1999, p. 489). The critical point here is that this esoteric conception does not necessarily mean that Corbin's project could not lead to any political or ideological program. On the contrary, some scholars demonstrate that his non-political and trans-historical definition of religiosity served exterior and temporal political purposes (Van den Bos 2002, p. 22). Moreover, as Carl Schmitt accurately observes, "any decision about whether something is unpolitical is always a political decision, irrespective of who decides and what reasons are advanced." This rule also holds for whether a particular theology is political or unpolitical (Schmitt 2005, p. 2). In this regard, the 
evaluation of Dariush Shayegan, a former disciple of Corbin, may clarify the ideological ramifications of Corbin's philosophy. The main problem of Corbin's project, according to Shayegan, is his trans-historical feature that does not appreciate the "spirit of time", and therefore, is prone to the ideologization of tradition. Furthermore, Shayegan observes that Corbin's dismissal of modern political values may easily lead his followers to the danger of anti-modern and reactionary ideologies (Shayegan 2011, pp. 358-66).

Some of Corbin's European disciples attempted to provide a new social or political theory based on Oriental wisdom, accepting the superiority of the imaginal realm over the terrestrial world. Two examples of social and political interpretations of Corbin's scheme are worth mentioning. First, Gilbert Durand was a French anthropologist who extensively discussed the role of imagination, symbolism, and myth in social life. Durand was significantly inspired by Corbin's theory of the imagination and mundus imaginalis, and his main enterprise was to provide a new account of sociology based on Eastern and imaginal elements (Durand 1964, 1971). In an extensive article entitled "Human science and Spiritual Islam," which was published in 1977 in a collected volume in honor of Corbin, he tried to sketch the outline of a social theory based on Oriental spirituality and the repudiation of "occidental and modern thought" (Durand 1977, p. 35). In this article, Durand's discussion rests heavily upon Corbin's perceptions, trying to make use of them in providing Oriental political sociology, or what he calls sociosophie, whose subject would not be the material mechanism but "the imaginal reality" of a community (Durand 1977, p. 79). The sociosophy defines society based on a "hierarchical sodality" (Durand 1977, p. 65) rather than horizontal concepts such as class. Durand's work could be construed as a right-wing political version of Corbin's project. Another important figure is Christian Jambet, especially in his The Logic of the Orientals, which provided a left-wing interpretation of the Oriental scheme (Jambet 1983). Both of the above thinkers believe that "verticality" can be seen as the hallmark of Corbin's theological project. As Steinbock observed, in Corbin's thought like anywhere else, "Vertical experience, has, not a dialectical, but an absolute nature" (Steinbock 2007, p. 112). Therefore, this vertical and absolute cosmic worldview, which is crystallized in the works of Corbin, may be transformed into radical and absolute ideologies. In the next section, I will discuss this influence in the works of some Iranian nativist intellectuals.

\section{Corbin's Legacy and Iranian Nativism}

It was Corbin who, for the first time in contemporary Iran, devised the idea of the East in the sense of illumination, drawn from Suhrawardi and other Iranian philosophers and mystics, and by doing so, exerted a significant influence on Iranian intellectuals' view of their tradition and shaped an authentic Eastern identity based on it (Walbridge 2001, p. 86). As S.H. Nasr has said, "Corbin's contribution to intellectual and philosophical self-awareness in Iran must never be forgotten" (Matin-Asgari 2018, p. 198). As mentioned above, Corbin was not a political thinker and did not discuss Iranian intellectual history from a political and social perspective. On the other hand, his conception of an East/West opposition was not geographical but spiritual and symbolic. However, his oriental scheme paved the way for a variety of ideologies, which shared in the radical rejection of the political, social, and cultural West (European and North-American modern countries) and a romantic admiration of an idealized East. As Van den Bos accurately asserted, his heritage would develop a life of its own and attain "temporally distinct political meanings that were exterior to the intentions" of Corbin himself (Van den Bos 2005, p. 118). In the critical period between 1953 and 1979, Corbin's discourse of authenticity, tradition, and spirituality, which was based on the East/West esoteric split, provided intellectual and conceptual logistics for the ideologies that were supposed to answer questions regarding Iranian identity, modern values, a potential return to tradition, and the true extent of imitation from Western countries. In a few of his writings and interviews, Corbin criticized Western values, insisting that the 20th-century crises, e.g., totalitarian movements and regimes, stemmed from modern historicism, secularism, and materialism, which are rooted 
in Western obliviousness to the spiritual and imaginal realms. He concluded that the "fate" of the West was to reject the Avicennian celestial souls, which led to the doctrine of "double truth," while in Iran, the imaginal world was a barrier in front of secularization. Therefore, Corbin, based on a theory of political theology similar to Schmitt's account, noted that modern political and social issues result from their theological tradition in a secularized version. The idea of divine Incarnation in Christian Catholic theology and the division between philosophy and theology in the West, according to him, is at odds with the esoteric and imaginal conception of "epiphany" and the presence of the sacred in the Iranian world. Consequently, the Iranian tradition, which has kept alive its "Oriental" origins and stands against the disenchantment of the world, seemed more authentic to him (Corbin 1985, pp. 129-31).

This idea of Eastern authenticity, coupled with his harsh critique against Western civilization, helped Iranian intellectuals provide various ideologies based on Corbin's East/West opposition. In these ideologies, features such as esotericism, verticality, the hierarchical world, and Eastern authenticity took an ideologized form to construct an Eastern identity against the West. According to the mentality of these intellectuals, Corbin was construed as a Western philosopher who, after years of contemplation and investigation, had come up with the idea that Western civilization was in its final stages and that the new epoch would be the age of the return to Eastern values and civilizations. Thus, the crisis and alienation of the West was a significant theme of almost all nativist intellectuals. Nevertheless and paradoxically, this radical critique of the West was often drawn not from Eastern doctrines but was based on European critiques from either left (e.g., Marx, Lenin, Sartre, and Marcuse) or right-wing thinkers (e.g., Oswald Spengler, Ernst Jünger, and Martin Heidegger).

Ahmad Fardid, an influential philosopher, was one of the first intellectuals who supported this anti-modern discourse. In 1946, Fardid translated a lecture series by Corbin (delivered in Tehran) on Suhrawardi's philosophy of illumination and its Zoroastrian origins (Corbin 1946). This book is an important work about Iranian "Oriental" authenticity and its persistence throughout history. As Ehsan Shari'ati rightly noted,

"Corbin had an important role in Iran and made the Iranian intellectuals confident that they had much to say in the world. ... Corbin called for a revision and reevaluation [of this cultural heritage], a theme that also reverberated throughout his primary lecture in Iran, to which Fardid was attracted. Thus, it was Corbin who devised the idea of the East-in the sense of Illumination philosophy and not the geographical sense-for the first time... Of course Corbin had an important role in the classification of issues in terms of Eastern and Western categories, and Fardid himself, who had both seminary education as well as mystical inclinations, followed Corbin and also learned from Heidegger that the history of metaphysics and the West is 'forgetfulness of Being' and ignorance. Fardid turned his focus to the East and introduced intuitive knowledge as an alternative". (Shari'ati 2018, p. 205)

Fardid's scheme included a kind of bridging of Heidegger's ontological phenomenology and the theoretical mysticism in the Islamic tradition, particularly Ibn Arabi (Hashemi 2007, pp. 76-87; Ashouri 2004). This mixture provided a critique of the West, which later was used by some other intellectuals like Al-e Ahmad. Some scholars noted that, concerning the East/West split, Fardid was significantly influenced by Corbin, ${ }^{5}$ who was the disciple of Heidegger and an acknowledged expert on Ibn Arabi. Fardid's conception of East and West, to some extent like that of Corbin, was not necessarily geographical. However, he went beyond Corbin by regarding this duality within a specific historiosophy, while the messianic and historical aspects of the Eastern wisdom had no significance to Corbin. Fardid's vision of historical consciousness was drawn from some aspects of Heidegger's thought, especially his conception of the end of metaphysical thinking and the need for philosophical inception (Green 2005, p. 224), as well as Ibn Arabi's theoretical mysticism, especially regarding the science of Names (Hashemi 2007, pp. 76-94). 
Fardid was the one who coined the well-known expression gharbzadegi (Westoxication), in which the West (ghrab) was not confined to the modern European period. However, he considered Greek philosophy and civilization as the West using a similar neologism: yunānzadegi, or the Greek-toxication. He even applied it to Islamic philosophy, charging Muslim thinkers such as Avicenna and Mulla Sadra as being 'Westoxified'. Fardid's formulation was followed by Al-e Ahmad and used for providing a more extensive account of Westoxication in his book under the same title. Unlike Fardid, Al-e Ahmad was a very popular intellectual as well as a prominent writer. That is why the concepts of gharbzadegi and gharbzadeh were rapidly spread and widely used by Iranian media in the 1970s. Al-e Ahmad's usage of the term was different from what was meant in both Corbin and Fardid by the term (Hashemi 2007, pp. 148-50). His definition of the West was mainly based on technology, attempting to condemn Western machinism's threat to Iranian culture and identity. His analysis was noticeably inspired by Marxist, existentialist, and post-colonial theories (Al-e Ahmad 1997, pp. 21-23). However, the symbolic opposition between the East and the West remained the hallmark of his anti-modern scheme.

Another important figure of this period is S.H. Nasr, an influential philosopher close to the court and one of the most prominent nativist intellectuals. Following René Guénon and Frithjof Schuon, Nasr has always been an integral Traditionalist. However, when he was a student, and before his acquaintance with Traditionalism, he was inspired by Corbin's Oriental Philosophy and especially his Oriental scheme (Abaza 2000, p. 93). He states that

"Already at Harvard I had read the books of Corbin, whom I did not meet until I came back to Iran in 1958. I had especially concentrated on his book Avicenne et le récit visionnaire ... and also his writings on Suhrawardi. These works had already pointed to what I had intuited concerning the significance of later philosophical thought in Iran". (Nasr and Jahanbegloo 2010, pp. 80-81)

Corbin's discovery of the symbolic and spiritual dimensions of this critical opposition between the East and the West highly inspired the young Nasr in writing his Ph.D. dissertation, which was primarily devoted to Iranian and Muslim medieval thinkers on the "sacred geography" (Nasr 1978, p. 89). The very idea was rooted in Henry Corbin's scheme of the symbolical topography, based on the imaginal world, extensively discussed in his book on Avicenna's recitals (Corbin 1960, p. 229). Nasr concludes from the symbolic tale of the Occidental Exile that "one must shed all material attachments and carnal desires to return to one's divine origin" (Boroujerdi 1996, p. 122). His view on the contemporary East/West distinction could be understood based on this geographical symbolism within an anti-western ideological formulation, articulated by himself in the following principles:

"1. Reviving the authentic intellectual traditions of Persia by resuscitating Islamic philosophy and mysticism; 2. Admonishing Iranians about the nature of Western sciences, philosophy, and technology and the risks that their acquisition will pose to Iranian culture, thereby enabling Iranians to view the West from the vantage point of a critical outlook rather than an inferiority complex; 3. Informing Iranians about cultures and civilizations of Asia as a possible counterbalancing force to Western influence; 4 . Attempting to delineate a way through which it would be possible to maintain Iranian cultural authenticity in the face of Western culture, technology, and sciences". (ibid, p. 124)

Like Corbin, Nasr also seemed not interested in political aspects of Iranian tradition in his works. However, he used the East/West spiritual symbolism of Corbin and Iranian philosophers to reject Western modernity based on an Eastern ground harshly. As the dean of the Faculty of Letters in the University of Tehran and the founding president of the Imperial Iranian Academy of Philosophy, Nasr also played an essential role in introducing and promoting Corbin's Oriental philosophy and the anti-West ideology to the Iranian academic atmosphere before the Islamic Revolution. ${ }^{6}$ 
Another nativist figure who played an important role as an ardent supporter of the East against the modern West is Ehsan Naraqi. A sociologist by training, he was the Institute for Social Studies and Research director, affiliated with the University of Tehran, and an intellectual voice of the "Return to the Self" in the 1960s and 1970s (Matin-Asgari 2018, p. 195). Naraqi was also inspired by some of Corbin's themes, including the East/West opposition, and attempted to apply them in order to offer a novel sociology, which would be based on authentic Oriental assumptions. For instance, he was highly attracted by Corbin's research on the Iranian tradition of fotowwat (chivalry) and javānmardi and translated Corbin's extended introduction to the edition of seven fotowwat-nameh from French into Persian when he was imprisoned after the Islamic Revolution (Corbin 1984). Naraqi was convinced that the correct social science for the Iranian community must be based on such indigenous concepts instead of the imitation and application of Western theories in an Iranian context.

Naraqi begins the first lines of his book Ghorbat-e Gharb ${ }^{7}$ (the Alienation of the West) with mention of Suhrawardi's recital, a text edited and extensively analyzed by Corbin. Naraqi notes that, according to Suhrawardi's recital, the East represents light and divine angels, whereas the West symbolizes the world of darkness and ignorance. Therefore, the modern West is the symbol denoting the spiritual downfall of human beings and their immersion in the material world. The actual place of humans, he noted, is the Eastern world. Interestingly, Naraqi recognized the fact that Suhrawardi would discuss the East/West opposition "from a different perspective," but still insisted that "anyway the Western man suffers from a certain kind of alienation from himself, from his dwelling, and finally from his fellow beings" (Naraqi 1974, pp. 9-10). What matters to him is to use the traditional symbolical topography to reject the modern West and embrace a romantic East. He develops this opposition with recourse to the opposition between Reality and Truth in Iranian tradition: the West is based on reality (science, technology, and material development), whereas the East is truth-oriented (faith, esotericism, mysticism). Therefore, the best option for Iranian society would be a combination of Western knowledge and Eastern vision, while the latter must restrain and control the former (Naraqi 1976, p. 11). ${ }^{8}$

Naraqi was one of the first intellectuals who put forward the idea of an indigenous social science based on Eastern values and assumptions. He made use of Corbin's scheme to formulate this idea, insisting on Corbin's idea according to which Iranian Islam must be studied "from within," regardless of its political, social, ethnic, economic, and geographical situation. Corbin's idealized, esoteric, and romantic conception of Iran/the East, coupled with his critique of objective, positivist, and secular anthropology (Naraqi 1976, pp. 175-79), convinced Naraqi that the solution would be a return to an Eastern "sociosophy" (a term coined by Durand) based on an esoteric and cosmic worldview, instead of Western sociology (Naraqi 1976, p. 176). In sum, Naraqi, like other nativist intellectuals, was thinking that Western and modern civilization could not and should not offer the Iranians either a lens through which they can understand themselves or the answers to their problems. Thus, the return to an authentic East, rooted in esoteric tradition, would be the correct answer to all the questions raised due to the encounter with modernity.

\section{Conclusions}

Henry Corbin played a significant role in shaping how Iranian nativist intellectuals view their own philosophical and spiritual traditions. His presence in Iran coincided with a sensitive period of government-based development and the rapid modernization of society, which produced strong reactions among intellectuals. In this situation, his Oriental scheme paved the way for various ideologies based on the rejection of the modern West and the praise of an idealized esoteric East.

Corbin was mainly interested in the Oriental philosophy of Avicenna and Suhrawardi, attempting to revive this philosophical tradition by trying to approve it as the main point of focus in Iranian tradition. According to him, this Oriental view has persisted throughout Iranian history from ancient Iran to the Islamic period. One of the critical aspects of this tradition is the symbolical topography, rooted in Avicenna andSuhrawardi's symbolical 
treatises, according to which the East is regarded as the site of eternal and esoteric truths. At the same time, the West symbolizes darkness, ignorance, and alienation. Corbin was the most crucial scholar who attempted to not only discuss this Oriental scheme, but also resuscitate and actualize it. Corbin's project was not a social or political scheme. His conception of the East/West opposition was a wholly spiritual and symbolic topography, a "sacred geography" which had nothing to do with the material and historical world. However, one can show that his Oriental scheme paved the way for political ideologies. Through the ideologization of tradition, Corbin's Oriental terminology was used as a weapon to fight against the Western civilization and its core values. On the other hand, his emphasis on Eastern authenticity inspired Iranian intellectuals to construct an identity discourse based on Iranian, Islamic, and Asian authenticity.

Funding: This research receives no external funding.

Institutional Review Board Statement: Not applicable.

Informed Consent Statement: Not applicable.

Data Availability Statement: Not applicable.

Conflicts of Interest: The author declares no conflict of interest.

\section{Notes}

1 This claim seems highly controversial. For instance, Hamid Algar rejects that "Corbin, consciously or unconsciously, aligned himself with the now defunct Iranian monarchy in the sense of placing his scholarship at its service". See: (Algar 1980, p. 90).

2 Corbin's account of Oriental philosophy has been criticized by some scholars (Gutas 2010, pp. 16-19). For different accounts of this term, see: (Gutas 2014; Strauss 1988, p. 125).

3 The distinction drawn by Corbin between symbol and allegory is highly controversial among Islamic scholars. For instance, Dimitri Gutas describes it as "highly subjective" and "quite inaccurate and misleading". (Gutas 2014, p. 337).

4 Compare with the evaluation of Ernst Cassirer of myth: "A myth is in a sense invulnerable. It is impervious to rational arguments; it cannot be refuted by syllogism." (Cassirer 1946, p. 296).

5 It should be noted that, despite this influence, Fardid was not mentioning the name of Corbin in a positive tone. After the triumph of the Islamic Revolution, he frequently insulted Corbin in his lectures. There is no room here to discuss this paradox. This fact is rooted in Fardid's political ambitions and some of his personal characters. For more discussion concerning this complicated relationship, see: (Ashouri 2004). For the influence of Corbin on Fardid, see, for instance: (Mirsepassi 2017, pp. 11-15; Abdolkaraimi 2012). And for a first-hand testimony on Fardid's view about Corbin before the Islamic Revolution, see: (Nasr 2018, pp. 55-72).

$6 \quad$ It also should be noted that Nasr was not wholly a "Corbinian." While he has been a Traditionalist, Corbin was against some aspects of Guénon's (and Schuon's) Traditionalism. See: (Sedgwick 2004, p. 157).

7 The term ghorbat in Persian can be translated to exile, alienation, and strangeness.

8 The English translation of the title of the book could be One's Own Possession (an allusion to a symbolic verse of Hafez: "the Heart was yearning for what already he had possessed") insisting that Eastern societies do not require Western and modern values, since they already had all the requirements of happiness and growth. In the book's preface, Naraqi noted that since this book is the sequel of his previous book (the Alienation of the West), he wanted at first to title the second book, The Reconciliation of the East (in Persian: Qorbat-e Sharq).

\section{References}

Abaza, Mona. 2000. A Note on Henry Corbin and Seyyed Hossein Nasr: Affinities and Differences. Muslim World 90: 91-106. [CrossRef] Abdolkaraimi, Bijan. 2012. Heidegger dar Iran. Tehran: Iranian Institute of Philosophy.

Adams, Charles. 1985. The Hermeneutics of Henry Corbin. In Approaches to Islam in Religious Studies. Edited by Richard Martin. Tuscan: University of Arzona Press.

Al-e Ahmad, Jalal. 1997. Gharbzadegi. Tehran: Rawaq.

Algar, Hamid. 1980. The Study of Islam: The Work of Henry Corbin. Religious Studies Review 6: 85-91. [CrossRef]

Ashouri, Dariush. 2004. Myth of Philosophy Amomg Us: A Review of Ahmad Fardid and the Theory of Westoxication. Available online: http:/ / ashouri.malakut.org/?attachment_id=205 (accessed on 8 September 2021).

Boroujerdi, Mehrzad. 1996. Iranian Intellectuals and the West: The Tormented Triumph of Nativism. Syracuse: Syracuse University Press. Boucharlat, Rémi. 2012. France xiii. Institut Français de recherche en Iran. Encyclopaedia Iranica X/2: 176.

Cassirer, Ernst. 1946. The Myth of the State. New York: Yale University Press. 
Cheetham, Tom. 2003. The World Turned Inside Out: Henry Corbin and Islmaic Mysticism. Woodstock: Spring Journal.

Corbin, Henry. 1946. Les Motifs Zoroastriens dans la Philosophie de Sohrawardi. Tehran: Edition du Courrier.

Corbin, Henry. 1960. Avicenna and the Visionary Recital. Translated by Willard Trask. New York: Pantheon Books.

Corbin, Henry. 1971. En Islam Iranien: Aspects Spirituels et Philosophiques Tome II. Paris: Gallimard.

Corbin, Henry. 1972a. En Islam Iranien: Aspects Spirituels et Philosophiques Tome III. Paris: Gallimard.

Corbin, Henry. 1972b. En Islam Iranien: Aspects Spirituels et Philosophiques Tome IV. Paris: Gallimard.

Corbin, Henry. 1981. De Heidegger à Sohravardi. In Cahier de l'Herne. Edited by Christian Jambet. Paris: Gallimard.

Corbin, Henry. 1984. Traités des Compagnons-Chevaliers. Tr. Ehsān Narāqi. Tehran: Nashr-e Now.

Corbin, Henry. 1985. Philosophie Iranienne et Philosophie Comparée. Paris: Buchet-Castel.

Corbin, Henry. 1989. Spiritual Body and Celestial Earth: From Mazdean Iran to Shi'ite Iran. Princeton: Princeton University Press.

Corbin, Henry. 1991. En Islam Iranien: Aspects Spirituels et Philosophiques Tome I. Paris: Gallimard.

Corbin, Henry. 1996. Swedenborg and Islamic Esotericism. Pennsylvania: Swedenborg Foundation Publishers.

Corbin, Henry. 2001. History of Islamic Philosophy. Translated by Liadain Sherrard. London: Kegan Paul International.

Durand, Gilbert. 1964. L'imagination symbolique. Paris: PUF.

Durand, Gilbert. 1971. Les Structures Anthropologiques de l'imaginaire. Paris: P. Bordas.

Durand, Gilbert. 1977. Science de l'homme et islam spirituel. In Mélanges offerts à Henry Corbin. Edited by Seyyed Hossein Nasr. Tehran: The Imperial Iranian Academy of Philosophy.

Elmarsafy, Ziad. 2021. Esoteric Islam in Modern French Thought: Massignon, Corbin, Jambet. Bloomington: Bloomsbury Academic.

Faivre, Antoine. 1994. Access to Western Esotericism. Albany: State University of New York Press.

Green, Nile. 2005. Between Heidegger and the Hidden Imam: Reflections on Henry Corbin's Approaches to Mystical Islam. Method E Theory in the Study of Religion 17: 219-26.

Gutas, Dimitri. 2010. The Study of Arabic Philosophy in the Twentith Century: An Essay on the Historiography of Arabic Philosophy. British Journal of Middle Eastern Studies 29: 5-25. [CrossRef]

Gutas, Dimitri. 2014. Avicenna and the Aristotelian Tradition. Leiden and Boston: Brill.

Hansen, Hendrik. 2009. Islamism and Western political religions. Religion Compass 3: 1026-41. [CrossRef]

Hashemi, Mohammad M. 2007. Identity Thinkers and the Intellectual Legacy of Ahmad Fardid. Tehran: Kavir.

Hillman, James. 2006. Archtypal Psychology: A Brief Account. Putnam: Spring Publications.

Hughes, Aaron. 2003. The Texture of the Divine: Imagination in Medieval Islamic and Jewish Thought. Bloomington: Indiana University Press.

Jambet, Christian. 1983. La Logique des Orientaux. Paris: Seuil.

Landolt, Hermann. 1999. Henry Corbin, 1903-1978: Between Philosophy and Orientalism. Journal of the American Oriental Study 119: 484-90. [CrossRef]

Matin-Asgari, Afshin. 2018. Both Eastern and Western. An Intellectual History of Iranian Modernity. Cambridge: Cambridge University Press.

Mirsepassi, Ali. 2017. Transnationalism in Iranian Political Thought: The Life and Times of Ahmad Fardid. Cambridge: Cambridge University Press.

Mirsepassi, Ali. 2019. Iran's Quiet Revolution. Cambridge: Cambridge University Press.

Naraqi, Ehsān. 1974. Ghorbat-e Gharb. Tehran: Amir Kabir.

Naraqi, Ehsān. 1976. Ancheh Khod dasht. Tehran: Amir Kabir.

Nasr, Seyyed Hossein, and Ramin Jahanbegloo. 2010. In Search of the Sacred: A Conversation with Seyyed Hossein Nasr on His Life and Thought. Santa Barbara: Praeger.

Nasr, Seyyed Hossein. 2018. For Fardid, Corbin Was Worthless, but, Shah Was Great. In Iran's Troubled Modernity. Debating Ahmad Fardid's Legacy. Edited by Ali Mirsepassi. Cambridge: Cambridge University Press, pp. 55-72.

Nasr, Seyyed Hossein. 1977. Henry Corbin- L'exil occidental: Une vie et une oeuvre en quête de l'Orient des Lumières. In Mélanges offerts à Henry Corbin. Edited by Seyyed Hossein Nasr. Tehran: The Imperial Iranian Academy of Philosophy, pp. 3-31.

Nasr, Seyyed Hossein. 1978. An Introduction to Islamic Cosmological Doctrines. London: Thames \& Hudson Ltd.

Rahman, Fazlur. 1975. The Philosophy of Mulla Sadra. Albany: SUNY Press.

Rousse-Lacordaire, Jérôme. 2006. Corbin, Henry. In Dictionary of Gnosis and Western Esotericism. Edited by Wouter Hanegraaff. Leiden/Boston: Brill, pp. 271-73.

Schmitt, Carl. 2005. Political Theology: Four Chapters on the Concept of Sovereignty. Translated by George Schwab. Chicago: The University of Chicago Press.

Sedgwick, Mark. 2004. Against the Modern World: Traditionalism and the Secret Intellectual History of the Twentieth Century. Oxford: Oxford University Press.

Shari'ati, Ehsan. 2018. Fardid Misunderstood Heidegger. In Iran's Troubled Modernity. Debating Ahmad Fardid's Legacy. Edited by Ali Mirsepassi. Cambridge: Cambridge University Press, pp. 196-215.

Shayegan, Dariush. 1991. Qu'est-ce qu'une révolution Religieuse? Paris: Albin Michel.

Shayegan, Dariush. 1992. Cultural Schizophrenia: Islamic Societies Confronting the West. Syracuse: Syracuse University Press.

Shayegan, Darisuh. 2011. Henry Corbin, penseur de l'islam spirituel. Paris: Alibin Michel.

Sohrevardi, Shihaboddin Yahya. 2001a. Oeuvres Philosophiques et Mystiques, Tome I. Edited by Henry Corbin. Tehran: Institut d'études et des Recherches Culturelles.

Sohrevardi, Shihaboddin Yahya. 2001b. Oeuvres Philosophiques et Mystiques, Tome II. Edited by Henry Corbin. Tehran: Institut d'études et des Recherches Culturelles. 
Steinbock, Anthony. 2007. Phenomenology and Mysticism: The Verticality of Religious Experience. Bloomington: Indiana University Press. Strauss, Leo. 1988. Persecution and the Art of Writing. Chicago: The University of Chicago Press.

Van den Bos, Matthijs. 2002. Mystic Regimes: Sufism and the State in Iran, from the Late Qajar era to the Islamic Republic. Leiden: Brill.

Van den Bos, Matthijs. 2005. Transnational Orientalism: Henry Corbin and Iran. Anthropos 100: 113-25.

Waardenburg, Jacques. 2002. Ideologization in Present-Day Islam: An Exploration. In Islam: Historical, Social, and Political Perspectives. Berlin/New York: Walter de Gruyter, pp. 317-34.

Walbridge, John. 2001. The Wisdom of the Mystic East: Suhrawardi and Platonic Orientalism. Albany: SUNY Press.

Wasserstrom, Steven. 1999. Religion after Religion: Gershom Scholem, Mircea Eliade, and Henry Corbin at Eranos. Princeton: Princeton University Press.

Ziai, Hossein. 2013. Shihab al-Din Suhrawardi: Founder of Illuminationst School. In History of Islamic Philosophy. Edited by Seyyed Hossein Nasr and Oliver Leaman. London and New York: Routledge. 